\title{
TRAGICZNA HISTORIA IZRAELSKO-ARABSKICH WALK POWIETRZNYCH. O KSIAZZŻE JAKUBA MARSZAŁKIEWICZA WALKI POWIETRZNE PODCZAS WOJEN IZRAELSKO-ARABSKICH ${ }^{1}$
}

\author{
Jarosław Centek \\ Uniwersytet Mikołaja Kopernika w Toruniu \\ Łukasz Mamert Nadolski \\ Muzeum Wojsk Lądowych w Bydgoszczy
}

\begin{abstract}
THE TRAGIC HISTORY OF ISRAELI-ARAB AERIAL COMBAT. ABOUT JAKUB MARSZAŁKIEWICZ'S BOOK, WALKI POWIETRZNE PODCZAS WOJEN IZRAELSKO-ARABSKICH
\end{abstract}

This article deals with the book Izraelsko-arabskie walki powietrzne [Israeli-Arab Aerial Combat] by Jakub Marszałkiewicz. Its author tries not only to summarise the aerial combats from the year 1948 to the present but also to show the beginnings of the Israeli Air Force. Unfortunately, this task seems to overwhelm him. The reviewed publication contains so many mistakes and ambiguities that it is impossible to analyse them fully in a review. As a result, only the most important ones are corrected. Marszałkiewicz does not refer to recent major publications related to his topic. He mostly draws on old books and articles published in Polish without even trying to verify their claims. Unfortunately, he has some difficulties with using other authors' works. Summing up, this is a book that not only brings nothing new to historiography but also preserves many old mistakes and myths, even adding new ones to the existing list.

Key words: Arab-Israeli wars, aerial combats, Israeli War of Independence, Suez Crisis, Six-Day War, Yom Kippur War, 1982 Lebanon War, Israeli Air Force.

Słowa kluczowe: wojny arabsko-izraelskie, walki powietrzne, wojna o niepodległość Izraela, kryzys sueski, wojna sześciodniowa, wojna Jom Kippur, pierwsza wojna libańska, Siły Powietrzne Izraela.

1 J. Marszałkiewicz, Walki powietrzne podczas wojen izraelsko-arabskich, Warszawa 2016, ss. 142 .

Adres do korespondencji: jcentek@umk.pl, mamertnad@wp.pl 


\section{UWAGI OGÓLNE}

Na wstępie trzeba zaznaczyć, że Jakub Marszałkiewicz prawdopodobnie nie rozumie, że walki powietrzne to starcie dwóch maszyn latających - samolotów, bezzałogowych statków powietrznych, a w początkach lotnictwa także zwalczanie sterowców i balonów. Walkom powietrznym poświęca on zdecydowanie mniejszą część swojej książki, niepotrzebnie przy tym prezentując nieprawdziwy i najeżony błędami obraz walk na ziemi.

Należy podkreślić, że J. Marszałkiewicz nie wykorzystał podstawowej literatury poświęconej lotniczym aspektom wojen na Bliskim Wschodzie. Nie chodzi tu tylko o klasyczne już publikacje anglojęzyczne ${ }^{2}$, ale także o najnowszą literaturę w tym języku ${ }^{3}$. Nie dotarł nawet do prac poświęconych walkom Izraela z jego arabskimi sąsiadami, wydanych w języku polskim ${ }^{4}$. W takiej sytuacji wysuwanie zarzutu braku materiałów po hebrajsku czy arabsku jest pozbawione sensu.

W tym miejscu wydaje się także zasadne wskazanie błędów, które powinny zostać wychwycone na etapie wydawniczej pracy nad tekstem. Książka J. Marszałkiewicza roi się od powtórzeń, na przykład: „Następnie wprowadzono już głównie sprzęt radziecki. W październiku 1955 r. pierwsze MiGi-15 wprowadzono [...]” (s. 52). Brak także choćby ujednolicenia pisowni, na przykład Dassault Mystère występuje raz $\mathrm{z}$ akcentem, a raz bez niego, najpierw jest Szerut $\operatorname{Awir}^{5}$ (s. 14), a potem Sherut Avir (s. 15). Niektóre miejscowości mają angielskie nazwy: zamiast Gazy pojawia się Gazah (s. 61), zamiast Dżuddy jest Jedda (s. 69) itd.

Do tego dochodzi budzący poważne wątpliwości sposób traktowania przez J. Marszałkiewicza prac innych autorów. Przykładowo tekst przypisów 28 (s. 27 i n.) oraz 47 (s. 38) został przepisany z polskiej Wikipedii, bez podania źródła! Rozdział dotyczący kryzysu sueskiego w 1956 roku miał zostać „głównie” oparty na pracy

2 Jak choćby: E. Cohen, Israel's Best Defense, Shrewsbury 1994; B. Norton, Air War on the Edge: A History of the Israeli Air Force and Its Aircraft since 1947, Hinckley 2004; E. Yonay, No Margin for Error: The Making of the Israeli Air Force, New York 1993.

3 Na przykład: S. Aloni, Israeli Mirage III and Nesher Aces, Oxford 2004; idem, Israeli F-4 Phantom II Aces, Oxford 2004, idem, Israeli F-15 Eagle Units in Combat, Oxford 2006; idem, Israeli A-4 Skyhawk Units in Combat, Oxford 2009; L. Nordeen, D. Nicolle, Phonix over the Nile: A History of Egyptian Air Power 1932-1994, Washington-London 1996; D. Nicolle, T. Cooper, Arab MiG-19 \& MiG-21 Units in Combat, Oxford 2004, czy też seria Arab Migs wydawana w latach 2009-2015, której spiritus movens był Tom Cooper.

4 Jak choćby: Ch. Herzog, Wojna Jom Kippur, Warszawa 2000; K. Kubiak, Suez 1956, Gdańsk 2006; Ł.M. Nadolski, Wojna Yom Kippur 1973, Gdańsk 2008; K. Gebert, Miejsce pod słońcem: wojny Izraela, Warszawa 2008; K. Kubiak, Wojna o niepodlegtość Izraela 1947-1949, Zabrze 2013; P. Tyler, Twierdza Izrael. Zakulisowa historia elit wojskowych, które uparcie broniq się przed pokojem, Poznań 2014; K. Kubiak, Ł.M. Nadolski, Wojna sześciodniowa 1967, Zabrze-Tarnowskie Góry 2015. Nawet jeżeli niektóre mają charakter ogólny (Gebert) czy są kontrowersyjne (Tyler), to stanowią dobre wprowadzenie ogólne w problematykę wojen izraelsko-arabskich. Brak także stricte lotniczych artykułów, np. P.A. Tesař, Izralskie „tajemnice” - Dassault Mystère, „Lotnictwo” 2012, nr 8.

5 Jako ciekawostkę można dodać, że rzekomo „hebrajska” nazwa (s. 14) zapisana jest od lewej do prawej! 
T. Coopera, a w rzeczywistości w znacznej części jest zlepkiem fragmentów z niej przetłumaczonych! Oto przykład, który pozostawiamy do oceny Czytelnikom:

Seven Canberras of the 10, 15, 44, and 139 Sqn then dropped 41 bombs caliber $454 \mathrm{~kg}$ over the same airfield, and reported to have caused damage on the hangars and several transport aircraft. Later, however, the British had to find out with horror that this attack was actually flown against Cairo West, but that no damage was caused at all. Minutes later, the first Valiants arrived over Almaza and dropped their bombs on the runways. By now the EAF already started reacting: the newly established radar-net was functional and three Meteor NF.13s of the 10 Sqn were scrambled to intercept. One of these was vectored into a favorable position behind one of the Valiants, causing the pilot to initiate a series of hard evasive maneuvers ${ }^{6}$.

I wersja J. Marszałkiewicza (s. 62):

7 bombowców Canberra z Dywizjonów 10., 15., 44. i 139. zrzuciło tam 41 bomb o masie $454 \mathrm{~kg}$ każda. Ich załogi donosiły o trafieniu hangarów i kilku samolotów transportowych. Później okazało się jednak, iż rzeczywiste zniszczenia po tym nalocie były symboliczne. Kilka minut później pierwsze naloty dotarły nad Almaza i zrzuciły bomby na drogi startowe. W tym momencie interweniowały egipskie myśliwce. Brytyjczycy zostali wykryci przez egipski system radarowy (który, jak widać, nie zdołał wykryć brytyjskich bombowców wcześniej), a do ich przechwycenia najpierw wystartowały 3 egipskie Meteory NF.13 z 10. Eskadry. Jednego $\mathrm{z}$ nich obsługa radaru naprowadziła na dogodną do strzału pozycję za bombowcem Valiant. Meteor nie trafił, ale zmusił Valianta do wykonania ostrych manewrów.

W polskiej „wersji” brakuje kluczowej informacji o pomyłce Brytyjczyków, którzy zbombardowali lotnisko Kair Zachodni, a nie Almaza.

W tekście, dotyczącym przecież walk powietrznych, w ogóle nie pojawia się kwestia zawyżania zestrzeleń przez walczących lotników. Jak rozumiemy, J. Marszałkiewicz uważa, że każde izraelskie zgłoszenie jest potwierdzone. Wyraźnie to także widać na przykładzie syryjskich zestrzeleń w 1979 i 1982 roku. Autor opiera swoje twierdzenia na artykułach A. Poraya, w żaden sposób nie próbując ich weryfikować.

Wytknięcie wszystkich błędów w recenzowanej publikacji znacznie powiększyłoby objętość niniejszego tekstu, a w zasadzie wymusiłoby napisanie książki o podobnej objętości. Z konieczności zatem poniżej wykazane zostaną tylko wybrane uchybienia.

\section{POWSTANIE I ROZWÓJ SIŁ LOTNICTWA NA BLISKIM WSCHODZIE ORAZ WOJNA W LATACH 1948-1949}

Połowa rozdziału o powstaniu lotnictwa izraelskiego nie ma nawet jednego przypisu. Możemy się domyślać, że tekst ten powstał na podstawie artykułu P. Przymusiała z 1990 roku. Autor powinien się zdecydować, czy pisać publikację z przypisami, czy też bez nich.

6 Suez Crisis, 1956: The War of Stripes, http://www.acig.info/CMS/index.php?option=com_conten t\&task=view\&id=206\&Itemid=47 [dostęp: 26.12.2016]. 
J. Marszałkiewicz nie opisuje, nawet pokrótce, powstania lotnictw państw arabskich. Dostajemy tylko informacje (s. 16), że Egipcjanie dysponowali: „40 myśliwcami Spitfire Mk. VC/Trop i Mk. IX, 25 DC-3 Dacota [sic! - wyróżnienie rec.] z możliwością przenoszenia bomb, 5 Hawker Fury, 20 Westland Lysander". Autor nie wyjaśnia, czy chodzi tu o wszystkie samoloty, czy też tylko o sprawne. Do tej informacji nie ma przypisu. Tymczasem Egipcjanie posiadali około 20 sprawnych spitfire'ów obu typów, drugie tyle nie nadawało się do lotu. Rzeczywista liczba maszyn bojowych była jednak znacznie większa - tylko spitfire'ów Mk. IX otrzymano od Brytyjczyków 41! Egipcjanie nie mieli DC-3, ale jego wojskową wersję (C-47), i to tylko 10 maszyn (większość była sprawna), a nie 25. Samolotów Hawker Sea Fury nie było pięć, tylko jeden. Został on przysłany przez Brytyjczyków w celach „reklamowych”; Egipcjanie przejęli go i wykorzystali w działaniach bojowych. Autor nie wspomina o posiadaniu przez Egipcjan kilkunastu maszyn T-6 Harvard, których użyto $\mathrm{w}$ atakach na cele naziemne ${ }^{7}$.

Kuriozalna jest informacja o pierwszym nalocie egipskim 15 maja 1948 roku. Na stronach 16 i 17 dowiadujemy się, że jeden spitfire LF Mk. IX zaatakował stację energetyczną w pobliżu bazy Lod, został zestrzelony, przejęty, wyremontowany i włączony do izraelskiego lotnictwa. W rzeczywistości sześć spitfire’ów (trzy pary) zaatakowało lotnisko Sde Dov w Tel Awiwie, niszcząc lub uszkadzając kilka samolotów. Jedna maszyna trzeciej pary została zestrzelona (przelatywała w tym czasie obok stacji energetycznej). Spitfire nie nadawał się do remontu. Wymontowano z niego część silnika, którą wykorzystano w samolocie numer D-130, złożonym z kilku zestrzelonych maszyn wroga. W ten sam sposób powstała później druga maszyna D-131. Podsumowując: nie jeden, a sześć, nie stacja energetyczna, ale lotnisko, nie wyremontowany, ale wykorzystany (w małym stopniu) jako dawca części zamiennych ${ }^{8}$.

Na stronie można 19 znaleźć informację, że Izraelczycy „pertraktowali” w Czechosłowacji zakup 50 spitfire'ów Mk. IX i Mk. XVI. W rzeczywistości były to tylko Mk. IX. Ani Czechosłowacy, ani Żydzi nigdy nie posiadali na swoim wyposażeniu nowszych spirfire'ów Mk. XVI' .

Dalsze dwie strony (20-21) to cały ciąg błędów i niedopowiedzeń. Działania wojenne zostały rzekomo wznowione 9 lipca 1948 roku, w rzeczywistości stało się to dzień wcześniej ${ }^{10}$.

7 L. Nordeen, D. Nicolle, op. cit., s. 58, 70-73, 90; B. Cull, S. Aloni, D. Nicolle, Spitfires over Israel, London 1994, s. 62, 117.

8 B. Senior, New Heavens: My Life as a Fighter Pilot and a Founder of the Israel Air Force, Washington 2005, s. 175-180; S. Różyński, Samoloty RWD - producenci, konstruktorzy i użytkownicy, praca magisterska, Uniwersytet Mikołaja Kopernika, Toruń 2009 (maszynopis niepublikowany), s. 274; K. Kubiak, Wojna o niepodległość Izraela..., s. 159; B. Norton, op. cit., s. 114; L. Nordeen, D. Nicolle, op. cit., s. 82; B. Cull, S. Aloni, D. Nicolle, op. cit., s. 126-129.

9 B. Norton, op. cit., s. 114-121.

10 M. Jadwiszczok, Pierwsza wojna izraelsko-arabska 1948 roku i jej wpływ na formowanie się Izraelskich Sił Obronnych, praca doktorska, Uniwersytet Adama Mickiewicza, Poznań 2010 (maszynopis niepublikowany), s. 196-197. Warto zwrócić uwagę, że J. Marszałkiewicz nie korzysta z tego bardzo dobrego doktoratu, który dostępny jest jako pdf w Internecie. 
Opisując pierwszy nalot B-17, autor twierdzi, że straty materialne były symboliczne - nie wiemy, czy zgodziłoby się z tym 30 zabitych Egipcjan. $Z$ tekstu wynika, że atak przeprowadzono 8 lipca. W rzeczywistości misja odbyła się 15 lipca $^{11}$.

J. Marszałkiewicz bardzo ogólnie opisuje ostatnią fazę wojny i nie wspomina nawet o największym starciu powietrznym działań bojowych (7 I 1949 r.), w czasie którego izraelscy lotnicy zestrzelili cztery samoloty brytyjskie. Następny został strącony przez obronę przeciwlotniczą ${ }^{12}$.

Podrozdział Późniejszy rozwój Sit Powietrznych Izraela nie odbiega poziomem od poprzednich. Autor powiela popularny mit, że we wszystkich wojnach (wymienia sześciodniową, kryzys sueski, Jom Kipur 1973 i walki nad doliną Bekaa w Libanie w 1982 roku oraz niepotwierdzone walki z Syryjczykami na początku XXI wieku - w tej kolejności) Izraelczycy posiadali mniej samolotów niż państwa arabskie jak rozumiemy, licząc tylko kraje bezpośrednio uczestniczące w walkach. Tak było w czasie wojny sześciodniowej, ale podczas kryzysu sueskiego lotnictwa izraelskie i egipskie były zbliżone pod względem liczebności ${ }^{13}$. W 1982 roku Izrael miał nad Syrią zarówno przewagę liczebną, jak i znaczącą przewagę technologiczną, podobnie było na początku XXI wieku' ${ }^{14}$.

Trudno się także zgodzić ze zdaniem: „Izraelskie lotnictwo niemal za każdym razem zadawało państwom arabskim szybki decydujący cios, który ratował państwo żydowskie przed inwazją i upadkiem" (s. 23). Szybkie skuteczne ciosy zadano tylko w 1967 i 1982 roku, ale za drugim razem nie było zagrożenia ,inwazją i upadkiem”. Autor w ogóle nie wymienia wojny na wyczerpanie, o której, co ciekawe, pisze w dalszej części książki.

Niestety dalej jest już tylko gorzej. Cztery zdania dotyczące historii F-15, zamieszczone na stronie 23, zawierają poważne błędy. ,[...] a do połowy 1982 roku bilans izraelskich Eagle'ow w walkach z syryjskimi myśliwcami wynosił już 15:0" - w rzeczywistości do połowy 1982 roku F-15 zgłosiły zestrzelenie 12,5 samolotu wroga ${ }^{15}$. „Dodatkowo F-15 użyte w roli maszyn myśliwsko-szturmowych zniszczyły 9 czerwca 19 syryjskich wyrzutni rakiet przeciwlotniczych w dolinie Bekaa" - w jednym zdaniu dwa błędy. Izraelczycy w tym czasie wykorzystywali maszynę McDonnell Douglas F-15 Eagle zgodnie z jej podstawowym przeznaczeniem, jako samolot przewagi powietrznej, nie wykonując ataków szturmowych. Eagle był zbyt cenny i skuteczny w zwalczaniu samolotów wroga. Liczba 19 dotyczy baterii rakiet przeciwlotniczych w dolinie Bekaa - każda składa się z kilku wyrzutni. Żydzi nie zgłosili zniszczenia 19 baterii, ale $14-15$ i uszkodzenie 2 kolejnych $^{16}$.

11 S. Aloni, Z. Avidor, Hammers. Israels's Long-Range Heavy Bomber Arm: The Story of 69 Squadron, Atglen 2010, s. 14-15.

12 B. Cull, S. Aloni, D. Nicolle, op. cit., s. 313-325.

13 B. Cull, Wings over Suez, London 2006, s. 84, 108.

14 A.H. Cordesman, A.R. Wagner, The Lessons of Modern War, vol. I: The Arab-Israeli Conflicts, 1973-1989, Boulder-San Francisco 1990, s. 193-194.

15 S. Aloni, Israeli F-15 ..., s. 88.

${ }^{16}$ A. Klein, S. Aloni, Israeli Phantoms The Kurnass in IDF/AF Service 1969-1988, Erlangen b.d., s. 119-120; S. Aloni, Z. Avidor, op. cit., s. 168-170; S. Aloni, Israeli F-15 ..., s. 44. 
„W tydzień po tej operacji izraelskie F-15 zestrzeliły około 45 syryjskich myśliwców (głównie MiG-21 oraz MiG-23)”. Według J. Marszałkiewicza 16 czerwca 1982 roku izraelskie F-15 strąciły 45 maszyn wroga. Tego dnia Izraelczycy nie zgłosili jednak żadnego zestrzelenia. Być może autorowi chodziło o to, że w ciągu tygodnia F-15 zestrzeliły 45 samolotów wroga, ale nadal jest to błędna informacja - pomiędzy 9 a 16 czerwca F-15 zgłosiły zestrzelenie 29 maszyn wroga (28 samolotów MIG-21 i 23 oraz jednego śmigłowca Gazelle) $)^{17}$.

„Innym znaczącym sukcesem maszyn tego typu było strącenie nieoznakowanego MiG-25”. W przypisie J. Marszałkiewicz dopowiada, że nie wiadomo, czy tych oznaczeń nie było, czy też izraelscy piloci ich nie dostrzegli, gdyż na tym typie samolotu są „bardzo niewielkie”. Izraelskie F-15 zgłosiły tymczasem zestrzelenie 2,5 syryjskiego MiG-a 25 (trzeciego wspólnie z baterią rakiet przeciwlotniczych MIM-23 Hawk). Biorąc pod uwagę, że wszystkie sukcesy osiągnięto za pomocą rakiet AIM-7, strzelając z dużej odległości - w pierwszym wypadku rakiety wystrzelono odpowiednio z 25 mil i 21 mil - to Izraelscy lotnicy nie dostrzegliby syryjskich oznaczeń, nawet gdyby pokrywały cały samolot. Warto dodać, że wrak trzeciej maszyny spadł na terytorium zajmowane przez Izrael ${ }^{18}$.

Na stronie 24 znajduje się informacja, że w ostatnich latach izraelskie lotnictwo nie toczyło walk powietrznych, gdyż arabscy partyzanci nie posiadali lotnictwa. Nie jest to do końca prawda. Hezbollah dysponuje samolotami bezzałogowymi, które były zestrzeliwane przez izraelskie myśliwce ${ }^{19}$.

Kolejne dwa podrozdziały poświęcone są testom MiG-ów przeprowadzonym przez Izraelczyków na zdobytym sprzęcie, a także polskiemu epizodowi wypożyczenia maszyn MiG-29. Na stronie 33 znajduje się kolejny poważny błąd. Autor pisze, że słynny samolot MiG-21 numer 007 był jedynym pozostawionym do obrony przestrzeni powietrznej Izraela pierwszego dnia wojny sześciodniowej. Nie jest to prawda. Żydzi pozostawili 12 myśliwców Mirage III, a także samolot MiG-21 numer $007^{20}$.

\section{KRYZYS SUESKI 1956 ROKU}

Na stronie 52 znajduje się informacja, że Izrael zakupił 18 samolotów Dassault Mystère IV. Autor zapomina zaznaczyć, że wcześniej kupiono sześć maszyn tego typu. W sumie daje to 24 samoloty $^{21}$. Na tej samej stronie dowiadujemy się, że Izrael pozyskał trzy maszyny „Gloster Gladiator NF.13”. Chodzi tu oczywiście o samoloty Gloster Meteor NF.13.

17 S. Aloni, Israeli F-15..., s. 87-88.

18 Ibidem, s. 32-34, 37-38, 63-64.

19 Israeli Air-to-Air Victories since 1974, http://www.acig.info/CMS/index.php?option=com_conte nt\&task=view\&id=201\&Itemid=47 [dostęp: 25.12.2016].

20 B. Norton, op. cit., s. 382.

21 B. Cul1, op. cit., s. 92. 
Niestety autor podaje więcej takich rewelacji. Na stronie 57 możemy przeczytać: „Około godziny 14.00 grupa 6 Mustangów ze 116. Eskadry wleciała w głąb Synaju z zadaniem przerwania linii telegraficznych za pomocą działek, podczepionych do kadłuba zwisających kabli lub nawet śmigieł". W tej pierwszej misji niszczenia kabli wzięły udział cztery mustangi, a nie sześć. Nie wykorzystano do tego „działek”, gdyż - po pierwsze - trafienie kabli, czy nawet słupów ich podtrzymujących, za pomocą pocisków graniczyło z cudem, a po drugie - mustangi nie miały na uzbrojeniu „działek", tylko wielkokalibrowe karabiny maszynowe (kaliber 12,7 mm ${ }^{22}$.

Na stronie 59 znajdujemy informację, że egipski niszczyciel „Ibrahim Al-Awal” ostrzelał Hajfę, uciekał w stronę Port Saidu, został zbombardowany przez samoloty Ouragan, którym pomagała „Dacota” (sic!), zrzucając flary. Ouragany nie zbombardowały, ale ostrzelały niszczyciel rakietami niekierowanymi. C-47 Dakota (a nie „Dacota”) ze 103. Dywizjonu nie zrzucał flar, gdyż był już dzień. Jego załoga pomogła natomiast odnaleźć okręt wroga ${ }^{23}$.

Podrozdział ten, jak wspomniano, to przetłumaczone fragmenty artykułu T. Coopera. Niestety nawet to przerosło J. Marszałkiewicza. Przykładowo na stronie 60 w przetłumaczonym zdaniu pomija informację o tym, że na pustyni lądowały tylko dwie z czterech uszkodzonych maszyn. Na tej samej stronie wspomina o atakach 117. Eskadry, podczas gdy w oryginale jest mowa o 105. i 117. Eskadrze. Prawdziwy popis stanowi natomiast wzmianka o „pasach inwazyjnych”, które malowano na samolotach celem ich szybkiej identyfikacji. J. Marszałkiewicz, spisując ten fragment od T. Coopera, uznał za stosowne dodać, że były one białe (s. 63)! Tymczasem nawet na stronie, z której korzystał ${ }^{24}$, zamieszczono barwne sylwetki maszyn z czarno-żółtymi pasami...

Trudność J. Marszałkiewiczowi sprawiła także egipska 1. Brygada Pancerna, która została - jego zdaniem - wykryta przez Egipcjan (,Egipcjanie wykryli egipską [...]"; s. 59, sic!). Najpierw została prawidłowo określona jako brygada, a później stała się już „1. Dywizją Pancerną” (s. 60), by kilka linijek dalej znów funkcjonować jako brygada (s. 60). Aż chce się zadać pytanie: co robił redaktor w trakcie lektury tego tekstu?

Novum stanowi twierdzenie, że Egipcjanie wysłali „trzy brygady wojskowe” do walki z okopującymi się spadochroniarzami. Do przełęczy Mitla skierowano tymczasem jedną brygadę ${ }^{25}$. Wysłanie wojsk na Synaj nie oznaczało przecież wprowadzenia ich do walki ze spadochroniarzami!

22 Ibidem, s. 116.

${ }_{23}$ K. Kubiak, Ł.M. Nadolski, Zdobycie niszczyciela Ibrahim el Awal-czyli o egipskich przewagach na morzu, „Militaria XX Wieku”, maj 2013, s. 32-35.

24 Suez Crisis, 1956: The War of Stripes, http://www.acig.info/CMS/index.php?option=com_conten t\&task=view\&id=205\&Itemid=47 [dostęp: 26.12.2016].

25 J. Centek, W serce Synaju - atak izraelskich spadochroniarzy na przelęcz Mitla [w:] Wojny i konflikty zbrojne po 1945 roku, t. 2, red. M. Giętkowski, Ł. Nadolski, Bydgoszcz 2016, s. 113. 
W ostrzale Port Saidu nie brał udziału „Richelieu” (na s. 56 błędnie zapisany jako „pancernik Richellieu”), tylko bliźniaczy „Jean Bart” (jak poprawnie na s. 71) ${ }^{26}$.

\section{WOJNA SZEŚCIODNIOWA}

Kolejny podrozdział, dotyczący wojny sześciodniowej, zaczyna kompletnie niepotrzebny wstęp ukazujący początki konfliktu izraelsko-arabskiego, będący powtórzeniem zaprezentowanych już informacji (s. 76). Dalej podane zostały informacje w większości przestarzałe, wymieszane z oczywistymi błędami.

Na przykład na stronie 84 autor pisze, że do godziny 8.00 Izraelczycy zniszczyli cztery bazy nieprzyjaciela. Zniszczenie tak rozległych kompleksów jak baza lotnicza jest bardzo trudne. Żydzi podziurawili pasy startowe (Egipcjanom udało się je potem załatać) i zniszczyli samoloty znajdujące się na nich. Na tej samej stronie można znaleźć informacje, że do godziny 8.00, w czasie ataków na lotniska, utracono między innymi jednego pilota, który został zestrzelony przez własną baterię rakiet MIM-23 Hawk. Rzeczywiście doszło do takiego incydentu, ale dopiero około godziny 14.00. Jeden z izraelskich samolotów został uszkodzony w czasie ataku na jordańską bazę, wleciał w strefę zakazu lotów i został zestrzelony przez rakietę przeciwlotniczą ${ }^{27}$.

Dalej znajduje się zdanie dotyczące wydarzeń 5 czerwca 1967 roku: „Podobno Irak wysłał jednego z 6 posiadanych bombowców Tu-16, by zbombardować Tel Aviv (mógł dokonać tam ogromnych szkód), jednak został zestrzelony przez obronę przeciwlotniczą Izraela". Opisany incydent zdarzył się 6 czerwca, a Irakijczycy wysłali cztery bombowce z 10. Dywizjonu przeciwko bazie Ramat David. Dwa zawróciły z przyczyn technicznych, trzeci zrzucił bomby w rejonie Afuli (jedna z nich zabiła dwóch cywilów), a czwarty na Netanię (jeden zabity cywil) i został zestrzelony wspólnym ogniem artylerii przeciwlotniczej i samolotu Mirage III. Spadający wrak zabił 14 izraelskich żołnierzy ${ }^{28}$.

Przy okazji dowiadujemy się, że „po kilku godzinach” zostały zniszczone także irackie bazy lotnicze. Nie jest to oczywiście prawda. Izraelczycy atakowali, zresztą w ciągu kilku dni, tylko bazę H-3, i to bez większych sukcesów, ponosząc przy tym poważne straty.

Na stronie 86 możemy znaleźć informację, że 5 czerwca 1967 roku Izraelczycy większość swoich samolotów stracili od ognia przeciwlotniczego. Ponownie autor się myli. Na 23 zestrzelone samoloty 12 strącili lotnicy przeciwnika, a kolejny rozbił się na skutek eksplozji maszyny wroga ${ }^{29}$.

26 G. Carter, Crises do Happen: The Royal Navy and Operation Musketeer, Suez 1956, Liskeard 2006, s. 141.

27 K. Kubiak, Ł.M. Nadolski, Wojna sześciodniowa..., s. 249-250.

28 Ibidem, s. 274-275.

29 Ibidem, s. 265-270. 


\section{WOJNA NA WYCZERPANIE I WOJNA JOM KIPUR}

Następny podrozdział dotyczy wojny Jom Kipur, znalazły się tu także informacje o wojnie na wyczerpanie. Na stronie 93 podano, że ZSRR skierował do Egiptu pięć pułków najnowszych myśliwców MiG-21MF. W rzeczywistości był to tylko jeden 135. Pułk Myśliwski ${ }^{30}$.

Nie jest to jedyny błąd autora związany z udziałem Sowietów w walkach na Bliskim Wschodzie. Na stronie 95 znajduje się informacja, że 25 lipca 1970 roku radziecki samolot MiG-21MF zestrzelił izraelskiego A-4. W rzeczywistości maszyna ze 102. Dywizjonu została tylko uszkodzona i bezpiecznie wylądowała w Refidim ${ }^{31}$.

Stronę dalej opisana jest walka izraelskich pilotów z sowieckimi, w czasie której „zestrzelono 5 MiGów-21MF (jednego za pomocą AIM-9 Sidewinder, jednego za pomocą pocisku średniego zasięgu AIM-7 Sparrow oraz jednego ogniem z działka)" (s. 96). Pozostałe dwa zostały staranowane? W rzeczywistości jeden został zestrzelony za pomocą AIM-7, a cztery - przy użyciu AIM-932. J. Marszałkiewicz nie wspomina także, że jeden ze „strzelających na oślep” Rosjan trafił rakietą powietrze-powietrze maszynę Mirage III, poważnie ją uszkadzając ${ }^{33}$.

Dalej autor przechodzi do opisu wojny Jom Kipur 1973 roku, rozpoczynając prawdziwy festiwal poważnych błędów. Już na początku dowiadujemy się, że siły izraelskie na wzgórzach Golan „musiały się wycofać” (s. 101). Wycofała się, zresztą tocząc zacięte walki, broniąca południowego odcinka frontu Brygada Barak. Walcząca na północ od Kuneitry 7. Brygada Pancerna w jednym z najsłynniejszych bojów wojen izraelsko-arabskich utrzymała zajmowane pozycje ${ }^{34}$.

Następnie autor opisuje straty izraelskiego lotnictwa pierwszego dnia wojny. Niestety brane są one z przysłowiowego kapelusza lub - dokładniej - ze starego kapelusza. I tak dowiadujemy się, że w ciągu pierwszych 30 minut wojny Izraelczycy stracili w czasie nalotów na wojska egipskie pięć A-4 Skyhawk i pięć F-4 Phantom (s. 102). Dalej zaś czytamy: „Z kolei za [wyróżnienie rec.] wzgórzach Golan lotnictwo izraelskie utraciło kolejnych 25 A-4 oraz 5 F-4". Rzeczywiste straty Izraela pierwszego dnia wojny to pięć A-4 (dwa nad wzgórzami Golan i trzy nad Kanałem Sueskim) oraz jeden F-4 ${ }^{35}$.

Na stronie 103 znajduje się prawdopodobnie najbardziej kuriozalne zdanie całej książki (a jest w czym wybierać): „Pod koniec drugiego dnia wojny syryjska obrona przeciwlotnicza była już mocno nadwyrężona i nie była w stanie osłaniać oddziałów pancernych, które zostały zdziesiątkowane przez lotnictwo Izraela". Z pewnością izraelskich obrońców wzgórz Golan bardzo ucieszyłaby taka sytuacja. Niestety nie

\footnotetext{
30 Совет ветеранов войны в Египте, http://www.hubara-rus.ru/kavkaz/ [dostęp: 26.12.2016].

31 S. Aloni, Israeli A-4 Skyhawk..., s. 28.

32 Idem, Israeli Mirage..., s. 84; idem, Israeli F-4 Phantom..., s. 86.

33 Idem, Israeli Mirage..., s. 62.

34 L.M. Nadolski, op. cit., s. 101-142; J. A sher, E. Hamme1, Duel for the Golan: The 100-hour Battle that Saved Israel, Pacifica 1987, s. 81-250.
}

35 A. Klein, S. Aloni, op. cit., s. 65; S. Aloni, Israeli $A-4 \ldots$, s. 82. 
ma to nic wspólnego z rzeczywistością. 7 października 1973 roku Izraelczycy przeprowadzili operację „Model-5” („Dougman-5”; ,5וגמן 5tóra miała doprowadzić do zniszczenia syryjskiego systemu obrony przeciwlotniczej na wzgórzach Golan. Akcja zakończyła się całkowitą klęską. Stracono sześć phantomów, nie osiągając $\mathrm{w}$ praktyce nic ${ }^{36}$. Warto podkreślić, że nazwa tej operacji nie pojawia się w recenzowanej książce.

Na wypadek gdyby J. Marszałkiewicz miał jakieś wątpliwości, zacytujmy dwa opracowania izraelskich autorów. Najpierw jedna z bardziej znanych historii izraelskiego lotnictwa, autorstwa E. Yonaya: „Klęska Dougman V była całkowita” ${ }^{37}$. I nowsza publikacja Shlomo Aloniego (z której J. Marszałkiewicz podobno korzystał): „Izraelskie Siły Powietrzne porzuciły próby osiągnięcia panowania w powietrzu i przez jakiś czas SAM wygrał z samolotem, chociaż Izraelczycy kontynuowali loty izolacji pola walki i bezpośredniego wsparcia lotniczego w obszary bronione przez SAM ${ }^{38 ”}$. Nawet Wikipedia, gdyby już nie było dostępu do innych źródeł, określa słusznie operację jako syryjskie zwycięstwo ${ }^{39}$.

Kilka wersów dalej możemy przeczytać: „W ciągu pierwszych 4 dni wojny Syria utraciła około 50\% stanu lotnictwa myśliwskiego i systemów przeciwlotniczych, natomiast lotnictwo izraelskie na froncie wschodnim tylko 6 maszyn". Straty syryjskie są oczywiście zawyżone. Bardziej interesujące wydaje się jednak zestrzelenie 6 maszyn izraelskich. Po pierwsze nie jest to liczba prawdziwa, a po drugie na stronie 102 (czyli jedną stronę wcześniej) możemy przeczytać, że na wzgórzach Golan Izraelczycy stracili w sumie 35 samolotów w ciągu pierwszych dwóch dni wojny! Warto przy tym dodać, że dla Izraela jest to front północny, a nie wschodni.

Na stronie 104 znajduje się następująca informacja: „W tym czasie pomocy arabskim sojusznikom próbował udzielić Irak. Brygadę pancerną, jadącą z Bagdadu do Damaszku, wykryły jednak izraelskie samoloty. Najpierw izraelscy komandosi wysadzili most, po którym owa brygada miała przejechać, i zaminowali drogę, a potem praktycznie unieruchomiony iracki zespól [wyróżnienie rec.] pancerny został zniszczony z powietrza przez izraelskie Phantomy”. Do powyższego incydentu nie doszło - phantomy nie zniszczyły ,zespołu” pancernego. W takiej sytuacji to, że „brygada pancerna” była w rzeczywistości 3. Dywizją Pancerną, która wykonała atak na skrzydło izraelskiego wyłomu na terenie Syrii, chyba już nie ma większego znaczenia $^{40}$.

Na tej samej stronie znajdują się też inne błędy, wśród których wyróżnia się następujące zdanie: „22 października izraelska brygada pancerna ponownie zajęła góry Hermon". Oczywiście chodzi o górę Hermon (a nie góry), zdobytą przez pododdziały Brygady Golani, 31. Brygady Spadochronowej i komandosów Sayeret Matkal. Nie trzeba dodawać, że żadna $\mathrm{z}$ tych jednostek nie była pancerna. Wsparcia Brygadzie Golani udzieliło osiem czołgów z 74. Batalionu Brygady Barak, przy czym

\footnotetext{
A. Klein, S. Aloni, op. cit., s. 68-69; Ł.M. Nadolski, op. cit., s. 289.

37 E. Yonay, op. cit., s. 334.

38 S. Aloni, Arab-Israeli Air Wars 1947-1982, Oxford 2001, s. 83.

39 Operation Model 5, https://en.wikipedia.org/wiki/Operation_Model_5 [dostęp: 27.12.2016].

40 Ł.M. Nadolski, op. cit., s. 159.
} 
uczestniczyły one tylko w natarciu na izraelską część góry. Decydującą rolę w tym starciu odegrali jednak żołnierze Brygady Golani, płacąc zresztą bardzo wysoką cenę za swój sukces ${ }^{41}$.

W podsumowaniu wojny Jom Kipur J. Marszałkiewicz stawia następująca tezę: „Izrael pokonał Syrię i Egipt głównie dzięki elastycznemu reagowaniu sił powietrznych. Lotnictwo okazało się czynnikiem decydującym, zdolnym skutecznie wspomóc armię, walcząc na dwóch frontach przeciwko dużo silniejszemu liczebnie przeciwnikowi”. Oczywiście powyższe założenia są błędne i chyba najlepiej ponownie oddać głos Izraelczykowi: „Dla Sił Powietrznych wojna nie została zakończona i na pewno nie była wygrana. [...] esencja wojny Jom Kipur została uchwycona przez Ezera Weizmana w krótkiej frazie na końcu jego autobiografii opublikowanej dwa lata później. »W czasie tej wojny - napisał - rakiety wygięły skrzydło samolotowi« - taki jest fakt" ${ }^{\prime \prime 2}$.

\section{OPERACJA „POKÓJ DLA GALILEI” I PÓŹNIEJSZE WALKI POWIETRZNE}

Przedostatni podrozdział książki opisuje działania nad Libanem na przełomie lat 70. i 80. XX wieku. Na stronie 111 znajduje się opis walk między 7 a 9 czerwca. Nie ma przy tym daty rocznej. Pojawia się ona na stronie 112 i tam opisane są wydarzenia z 27 czerwca 1979 roku. Logicznym wnioskiem jest stwierdzenie, że informacje ze strony 111 także dotyczą 1979 roku. Autor, opierając się na artykule A. Poraya ze „Skrzydlatej Polski”, twierdzi (s. 111), że 7 czerwca syryjskie samoloty MiG-23 zestrzeliły dwa izraelskie F-16 (,Fakt, że informacja została opublikowana przez »Skrzydlatą Polskę«, wskazuje, iż jest ona [informacja o zestrzeleniu dwóch F-16 - przyp. rec.] bardzo prawdopodobna”), 8 i 9 czerwca kolejne dwa. Jak zwykle J. Marszałkiewicz nie weryfikuje tego typu zgłoszeń. W rzeczywistości Syryjczycy nie zestrzelili żadnego F-16. W dniach 7-9 czerwca 1979 roku nie doszło do żadnych starć powietrznych. Można się domyśleć, że chodzi tu o wydarzenia z 1982 roku, ale z tekstu to nie wynika. Zresztą także w 1982 roku Izraelczycy nie stracili żadnego F-16.

Na stronie 113 otrzymujemy opis walki z 19 września (ponownie musimy się domyślać roku, jak się wydaje: 1979), do której nie doszło! Co więcej, jedno ze zwycięstw miało zostać osiągnięte przez F-15 za pomocą rakiety Shafrir - w rzeczywistości maszyny Eagle nie zestrzeliły tą rakietą żadnego samolotu wroga ${ }^{43}$.

Następnie J. Marszałkiewicz przechodzi do opisu zniszczenia syryjskiego systemu obrony przeciwlotniczej 9 czerwca 1982 roku (s. 118). Co ciekawe, tym razem dokonały tego „F-4, A-4, F-16 i Kfiry”, a nie F-15, jak twierdził autor na stronie 23.

\footnotetext{
${ }^{41}$ M. Har-Lew, Golani szeli, Tel-Awiw b.d., s. 141; Ł.M. Nadolski, op. cit., s. 167-169.

42 E. Yonay, op. cit., s. 355.

43 S. Aloni, Israeli F-15 .., s. 87.
} 
Dalej J. Marszałkiewicz, ponownie powołując się na artykuły A. Poraya, twierdzi, że 4 października 1982 roku syryjskie lotnictwo zestrzeliło dwa F-15, a 4 grudnia 1982 roku po jednym F-15 i F-4. Ponownie nie ma to nic wspólnego z rzeczywistością.

W podsumowaniu wojny 1982 roku autor twierdzi (s. $121 \mathrm{i} \mathrm{n.),} \mathrm{że} \mathrm{w} \mathrm{czasie} \mathrm{jej}$ trwania ,prawie nie używano pocisków średniego zasięgu (AIM-7E, R-23R/T)”. Bardzo ciekawe twierdzenie, biorąc pod uwagę, że w latach 1979-1982 izraelskie F-15, spośród 50 zgłoszonych zwycięstw powietrznych 15,5 odniosły za pomocą rakiet AIM-7. W wypadku samolotów MiG-23 większość „zestrzeleń” została osiągnięta przy wykorzystaniu R-23R ${ }^{44}$. J. Marszałkiewicz podaje również, że walki w 1982 roku pokazały, jak „strona dysponująca znaczną przewagą informacyjną może użyć relatywnie małej liczby samolotów i doskonale wyszkolonych pilotów, by odnieść zwycięstwo" (s. 122). Zdaje się przy tym zapominać, co sam pisał wcześniej - że Izrael miał przewagę liczebną 90 do 50 maszyn (s. 119).

Ostatni podrozdział opisuje potyczki powietrzne Izraela i Syrii, które miały zostać stoczone w 1989 i 2001 roku. Fragment ten powstał na podstawie artykułu Toma Coopera. Co ciekawe, w przypisie J. Marszałkiewicz zachwala tego autora, wymienia wiele jego publikacji, ale z żadnej nie korzysta, pisząc swoją książkę! Warto przy tym podkreślić, że z tekstu T. Coopera (źródło ich pochodzenia jest podane) pochodzą mapki ilustrujące przebieg walk powietrznych w tym okresie. Reprodukcje są czarno-białe, ale czytając opis do nich (rys. 2.31), można się domyślić, że w oryginale były kolorowe, a sam opis jest li tylko tłumaczeniem, gdyż J. Marszałkiewicz wspomina o tym, że ,żadna ze stron nie przekraczała czerwonych linii” oraz że „brązowe pola na mapie” oznaczają strefy „stałego patrolowania w powietrzu” (s. 130).

\section{PODSUMOWANIE}

Książka J. Marszałkiewicza jest publikacją szczególną. Niestety wyłącznie w negatywnym tego słowa znaczeniu. Stanowi zlepek informacji, zebranych jakby przypadkiem, w dodatku najeżonych błędami. Autor opiera swoje wywody na całkowicie przestarzałych materiałach, nie sięgając po nowsze publikacje, ani nawet wartościowe strony internetowe. Czytelnik nie znajdzie w niej żadnych poważniejszych analiz, których można byłoby się spodziewać, biorąc pod uwagę posiadanie przez J. Marszałkiewicza doktoratu z nauk o obronności. Publikacja ta ani nie wnosi nic nowego do obecnego stanu wiedzy (mamy tu na myśli historiografię polską, o powszechnej nie ma co nawet wspominać), ani nawet nie stanowi zgrabnej kompilacji wcześniejszych prac. Jest niestety po prostu szkodliwa, gdyż ze względu na ogromne nasycenie błędami może wprowadzić zamieszanie wśród czytelników mniej obeznanych z tematyką walk powietrznych w konfliktach izraelsko-arabskich.

${ }^{44}$ Ibidem, s. 88; Syrian Air-to-Air Victories since 1948, http://www.acig.info/CMS/index. php?option $=$ com_content\&task=view\&id=34\&Itemid=47 [dostęp: 28.12 .2016$]$. 
Również wydawnictwo nie stanęło na wysokości zadania. Mimo korekty i redakcji tekst nie został ujednolicony, pod względem stylistycznym (powtórzenia!) jest wręcz tragiczny.

\section{BIBLIOGRAFIA}

\section{Książki i artykuły}

Aloni S., Arab-Israeli Air Wars 1947-1982, Oxford 2001.

Aloni S., Israeli A-4 Skyhawk Units in Combat, Oxford 2009.

Aloni S., Israeli F-15 Eagle Units in Combat, Oxford 2006.

Aloni S., Israeli F-4 Phantom II Aces, Oxford 2004.

Aloni S., Israeli Mirage III and Nesher Aces, Oxford 2004.

Aloni S., Avidor Z., Hammers. Israels's Long-Range Heavy Bomber Arm: The Story of 69 Squadron, Atglen 2010.

Asher J., Hammel E.M., Duel for the Golan. The 100-hour Battle that Saved Israel, Pacifica 1987.

Carter G., Crises do Happen: The Royal Navy and Operation Musketeer, Suez 1956, Liskeard 2006.

Centek J., W serce Synaju - atak izraelskich spadochroniarzy na przetęcz Mitla [w:] Wojny i konflikty zbrojne po 1945 roku, t. 2, red. M. Giętkowski, Ł.M. Nadolski, Bydgoszcz 2016, s. 107-134.

Cohen E., Israel's Best Defense, Shrewsbury 1994.

Cordesman A.H., Wagner A.R., The Lessons of Modern war, vol. I: The Arab-Israeli Conficts, 1973-1989, Boulder-San Francisco 1990.

Cull B., Wings over Suez, London 2006.

Cull B., Aloni S., Nicolle D., Spitfires over Israel, London 1994.

Gebert K., Miejsce pod stońcem. Wojny Izraela, Warszawa 2008.

Har-Lew M., Golani szeli, Tel-Awiw b.d.w.

Herzog Ch., Wojna Jom Kippur, Warszawa 2000.

Klein A., Aloni S., Israeli Phantoms The Kurnass in IDF/AF Service 1969-1988, Erlangen b.d.

Kubiak K., Suez 1956, Gdańsk 2006.

Kubiak K., Wojna o niepodległość Izraela 1947-1949, Zabrze 2013.

Kubiak K., Nadolski Ł.M., Wojna sześciodniowa 1967, Zabrze-Tarnowskie Góry 2015.

Kubiak K., Nadolski Ł.M., Zdobycie niszczyciela Ibrahim el Awal - czyli o egipskich przewagach na morzu, „Militaria XX Wieku”, maj 2013, s. 32-35.

Nadolski Ł.M., Wojna Yom Kippur 1973, Gdańsk 2008.

Nicolle D., Cooper T., Arab MiG-19 \& MiG-21 Units in Combat, Oxford 2004.

Nordeen L., Nicolle D., Phonix over the Nile: A History of Egyptian Air Power 19321994, Washington-London 1996. 
Norton B., Air War on the Edge: A History of the Israeli Air Force and Its Aircraft since 1947, Hinckley 2004.

Senior B., New Heavens: My Life as a Fighter Pilot and a Founder of the Israel Air Force, Washington 2005.

Tesař P.A., Izralskie „, tajemnice” - Dassault Mystère, „Lotnictwo” 2012, nr 8, s. 66-77.

Tyler P., Twierdza Izrael. Zakulisowa historia elit wojskowych, które uparcie bronia się przed pokojem, Poznań 2014.

Yonay E., No Margin for Error: The Making of the Israeli Air Force, New York 1993.

\section{Opracowania niepublikowane}

Jadwiszczok M., Pierwsza wojna izraelsko-arabska 1948 roku i jej wpływ na formowanie się Izraelskich Sił Obronnych, praca doktorska, Uniwersytet Adama Mickiewicza, Poznań 2010 [maszynopis niepublikowany].

Różyński S., Samoloty RWD - producenci, konstruktorzy i użytkownicy, praca magisterska, Uniwersytet Mikołaja Kopernika, Toruń 2009 [maszynopis niepublikowany].

\section{Strony internetowe}

Israeli Air-to-Air Victories since 1974, http://www.acig.info/CMS/index.php?option=com content\&task=view\&id=201\&Itemid=47 [dostęp: 25.12 .2016$]$.

Operation Model 5, https://en.wikipedia.org/wiki/Operation_Model_5 [dostęp: 27.12.2016].

Suez Crisis, 1956: The War of Stripes, http:/www.acig.info/CMS/index.php?option=com_co ntent\&task=view\&id=206\&Itemid=47 [dostęp: 26.12.2016].

Syrian Air-to-Air Victories since 1948, http://www.acig.info/CMS/index.php?option=com content\&task=view\&id=34\&Itemid=47 [dostęp: 28.12 .2016$]$.

Совет ветеранов войны в Египте, http://www.hubara-rus.ru/kavkaz/ [dostęp: 26.12.2016]. 